\title{
Effect of MgO addition on the mechanical and thermal properties of mullite synthesised through reaction sintering of $\mathrm{Al}_{2} \mathrm{O}_{3}$ and Algerian kaolin
}

\author{
A. Ouali ${ }^{1}$, M. Heraiz ${ }^{1}$, F. Sahnoune ${ }^{1}$, H. Belhouchet ${ }^{2}$, M. Fatmi ${ }^{3,4, *}$, N. Saheb ${ }^{5}$ \\ ${ }^{1}$ Laboratory of Physics and Chemistry of Materials, University of M'sila, 28000, M'sila, Algeria \\ ${ }^{2}$ Laboratory of Non Metallic Materials, IOMP, University of Setif 1, 19000, Algeria \\ ${ }^{3}$ Research Unit on Emerging Materials (RUEM), University of Setif 1, 19000, Algeria \\ ${ }^{4}$ Laboratory of Physics and Mechanics of Metallic Materials (LP3M), University of Setif 1, 19000, Algeria \\ ${ }^{5}$ Department of Mechanical Engineering, King Fahd University of Petroleum and Minerals, Dahran, 31261, Saudi Arabia

\section{Email address:} \\ fatmimessaoud@yahoo.fr(M. Fatmi)
}

\section{To cite this article:}

A. Ouali, M. Heraiz, F. Sahnoune, H. Belhouchet, M. Fatmi, N. Saheb. Effect of MgO Addition on the Mechanical and Thermal Properties of Mullite Synthesised through Reaction Sintering of $\mathrm{Al}_{2} \mathrm{O}_{3}$ and Algerian Kaolin. American Journal of Modern Physics. Vol. 2, No. 5, 2013, pp. 270-275. doi: 10.11648/j.ajmp.20130205.16

\begin{abstract}
The influence of $\mathrm{MgO}$ addition on the structure and properties of mullite prepared through reaction sintering of Algerian kaolin and $\mathrm{Al}_{2} \mathrm{O}_{3}$ was investigated. The raw powders were wet ball milled, dried and cold compacted using a uniaxial press. The green compacts were sintered 8 hours at 1600 and $1650^{\circ} \mathrm{C}$. The microstructure of samples was characterized using a scanning electron microscope. Mechanical and thermal properties were characterized using Vicker’s hardness tester, a universal testing machine and a dilatometer. It was found that the increase of $\mathrm{MgO}$ content from 0 to 3 wt- $\%$ increased the hardness of samples sintered 8 hours at $1600^{\circ} \mathrm{C}$ from 1039 to $1316.57 \mathrm{HV}$. Also, the increase of $\mathrm{MgO}$ content in samples sintered 8 hours at 1600 and $1650^{\circ} \mathrm{C}$ increased the compressive strength up to a maximum then decreased it. For a sintering temperature of $1600^{\circ} \mathrm{C}$, the increase of $\mathrm{MgO}$ content up to $2 \mathrm{wt}-\%$ increased the flexural strength, but a further increase of $\mathrm{MgO}$ to $3 \mathrm{wt}-\%$ decreased it again, while for a sintering temperature of $1650^{\circ} \mathrm{C}$, the increase of $\mathrm{MgO}$ content from 0 to $3 \mathrm{wt}-\%$ increased the flexural strength from 103.45 to $472.25 \mathrm{MPa}$. Amongst $\mathrm{MgO}$ containing samples, the increase of $\mathrm{MgO}$ content increased the coefficient of thermal expansion; however, it remained lower than the coefficient of thermal expansion of the sample without $\mathrm{MgO}$ addition.
\end{abstract}

Keywords: Kaolin, Mullite, Alumina, Reaction Sintering, Mechanical Properties, Thermal Properties

\section{Introduction}

Synthesis of mullite from clay remains an economical way to prepare mullite and mullite based composites [112] ; because mullite powder compacts have poor solid state sinterability [13] and the production of dense mullite compacts requires relatively high sintering temperatures, many studies have been dedicated to investigate the effect of adding sintering aids such as $\mathrm{MgO}$ [14-20], $\mathrm{SrO}$ [21], $\mathrm{B}_{2} \mathrm{O}$ [22], $\mathrm{TiO}_{2}$ [23], $\mathrm{CeO}_{2}$ [24], $\mathrm{V}_{2} \mathrm{O}_{5}$ [25] and $\mathrm{Y}_{2} \mathrm{O}_{3}$ [26] on the densification and sinterability of mullite.

Although $\mathrm{MgO}$ is one of the most commonly used sintering aids in the processing of mullite, the amount of $\mathrm{MgO}$ to be used is still a matter of controversy [26]. It was reported that the addition of $\mathrm{MgO}$ above $0.5 \mathrm{wt} . \%$ has no effect in controlling mullite grain growth [14]. The efficiency of adding small amounts of $\mathrm{MgO}$ (below $0.5 \mathrm{wt} . \%)$ on the sintering of industrial mullite was evaluated by Souto and co-workers[26]. They found that the use of 0.1 and $0.5 \mathrm{wt} \%$ of $\mathrm{MgO}$ increased the final density of the sintered samples, with the doped samples reaching densities of $99 \%$ and the nondoped samples reaching densities of $95 \%$. Also, the use of $0.5 \%$ of $\mathrm{MgO}$ decreased the sintering temperature by approximately $100^{\circ} \mathrm{C}$. However, many authors have used larger amounts of $\mathrm{MgO}$, usually ranging from 1 to $5 \mathrm{wt} . \%$. Viswabaskaran et al. [5] reported that the addition of $\mathrm{MgO}$ increased the grain growth and thereby increased the density to maximum value. Also, they found that $\mathrm{MgO}$ enhanced the 
liquid phase sintering and they obtained a density value of $2.91 \mathrm{~g} . \mathrm{cm}^{-3}$ for the sample containing $3 \mathrm{wt} . \% \mathrm{MgO}$. Also, they concluded that the amount of $\mathrm{MgO}$ beyond $3 \mathrm{wt} . \%$ had induced bloating and thereby decreased the density. They achieved a strength of $126 \mathrm{MPa}$ for 3 wt.\% $\mathrm{MgO}$ added samples. In another investigation [18] they found that samples with 3.0 wt. $\% \mathrm{MgO}$ showed the presence of secondary phases such as $\alpha$-alumina and spinel; and mullite crystals formed were needle-shaped with rectangular faces; and the $\mathrm{MgO}$ (3.0 wt.\%) addition slightly decreased the thermal expansion. Doni Jayaseelan and co-workers [17] prepared industrial mullite compacts having near theoretical density using pulse electric current sintering at $1500^{\circ} \mathrm{C}$ for $2 \mathrm{~min}$. They found that the dopants influenced the morphology of mullite grains and hence the fracture mode. The fracture surface of $\mathrm{MgO}$ enriched mullite was highly crystalline in nature and the grains showed extensive fine cleavage.

In previous works we synthesised mullite through
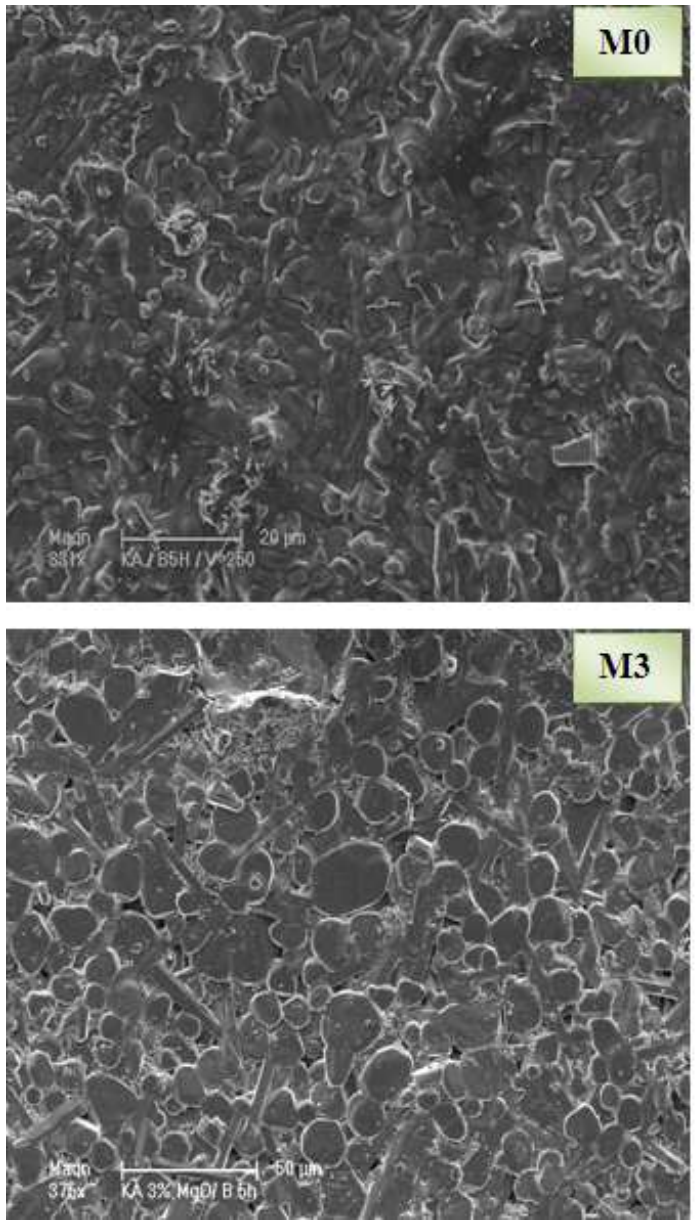

reaction sintering Algerian kaolin and $\mathrm{Al}_{2} \mathrm{O}_{3}$ [12] and investigated the kinetics of mullite formation from Algerian kaolin [27] and analysed its thermal dehydroxylation[28]. Also, we reported the effect of $\mathrm{MgO}$ addition on the structure and sintering behaviour of mullite [29] and found that in samples containing 0,1 and $2 \mathrm{wt}-\% \mathrm{MgO}$ only mullite was formed while, in addition to mullite, $\mathrm{Al}_{2} \mathrm{O}_{3}$ was present in samples containing $3 \mathrm{wt}-\% \mathrm{MgO}$. At higher $\mathrm{MgO}$ content $(4,5$ and 6 wt- $\%)$, three phases, i.e. mullite, $\mathrm{Al}_{2} \mathrm{O}_{3}$ and spinel, were formed. Addition of $1 \mathrm{wt}-\% \mathrm{MgO}$ increased the density of all samples for all sintering times and higher densities corresponded to higher sintering temperatures. At higher $\mathrm{MgO}$ content, higher temperatures led to lower densities and lower temperatures led to higher densities for almost all sintering times. The objective of the present work is to investigate the effect of $\mathrm{MgO}$ addition on the mechanical and thermal properties of mullite synthesised through reaction sintering of Algerian kaolin and $\mathrm{Al}_{2} \mathrm{O}_{3}$.
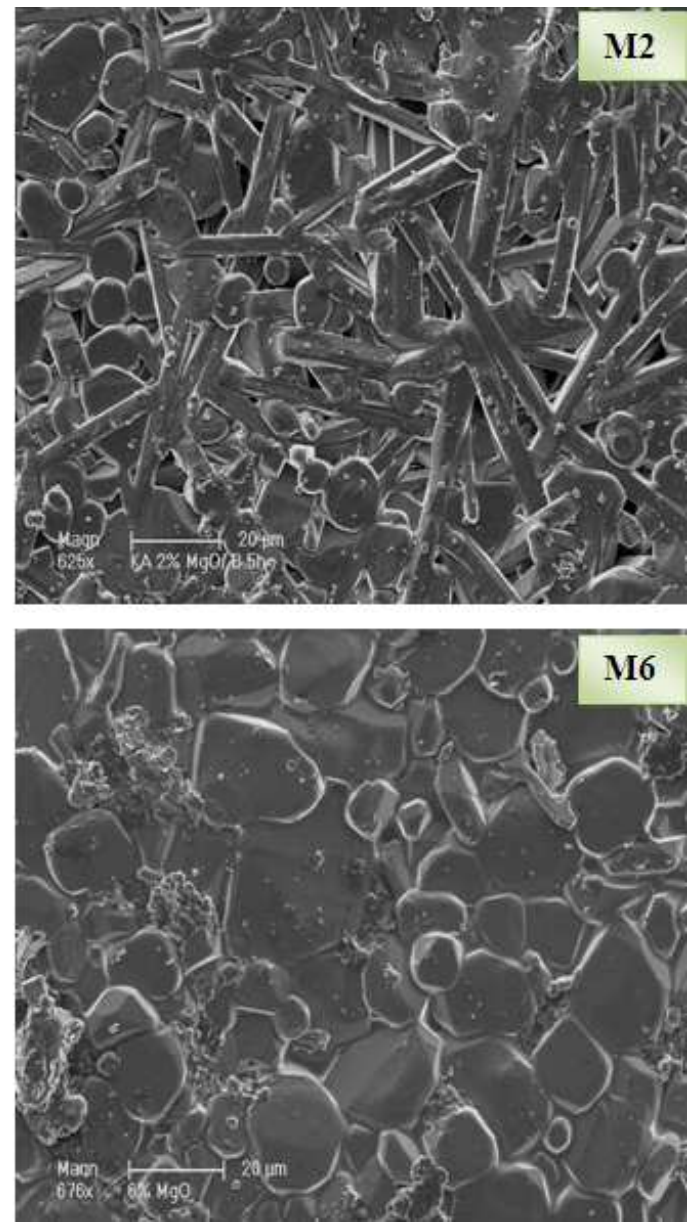

Figure 1. SEM micrographs of samples sintered at $1650^{\circ} \mathrm{C}$ for 8 hours.

\section{Materials and Experimental Procedures}

Algerian raw kaolin (from Djabal Debagh) was added to $\mathrm{Al}_{2} \mathrm{O}_{3}(99.98 \%$ purity, with average particle size of $0.5 \mu \mathrm{m})$ supplied by Fluka according to the stoichiometry that leads to the formation of mullite $\left(3 \mathrm{Al}_{2} \mathrm{O}_{3} \cdot 2 \mathrm{SiO}_{2}\right)$ only. Samples containing $\mathrm{MgO}$ (named $\mathrm{M} 0$ to $\mathrm{M} 6$ ) were prepared by addition of $0,1,2,3,4,5$ and $6 \mathrm{wt}-\%$ of $\mathrm{MgO}$ to the kaolin-alumina mixture. More information on the chemical composition of the kaolin and samples as well as the 
theoretical density of the samples is reported elsewhere $[12,27,29]$. The mixture of the powders was charged into zirconia vials $(250 \mathrm{ml}$ in volume $)$ together with 15 zirconia balls (10 $\mathrm{mm}$ in diameter). The ball-to-powder weight ratio was maintained as 10:1 and water was added at a ratio of $2: 1$. The ball-milling experiments were performed in a high-energy planetary ball mill (Fritsch P6) and were carried out at room temperature at a rotation speed of 250 rpm for 5 hours. The milled mixture was dried at $100{ }^{\circ} \mathrm{C}$ for 6 hours then cold compacted at $75 \mathrm{MPa}$ using uniaxial press. Cylindrical specimens of $13 \mathrm{~mm}$ diameter were produced. The green compacts were sintered in a furnace at 1600 and $1650^{\circ} \mathrm{C}$ for 8 hours. The heating rate was $10^{\circ} \mathrm{C} / \mathrm{min}$. The microstructure of samples was characterized using a JEOL scanning electron microscope (SEM) model JSM 5600. Vicker's hardness was measured by applying a load of $300 \mathrm{~g}$ on the polished surface of the specimens. The flexural strength was evaluated through three-point bending test using an INSTRON universal testing machine. Specimens having $8 \mathrm{~mm} \times 8 \mathrm{~mm} \times 50 \mathrm{~mm}$ and a crosshead speed of $0.5 \mathrm{~mm} / \mathrm{min}$ were used. Each reported value was an average of 5 measurements. The compressive strength of samples was measured using an INSTRON universal testing machine. The linear coefficient of thermal dilation and the relative variation length were measured using a dilatometer (DIL 402C).

\section{Results and Discussion}

Figure 1 shows SEM micrographs of samples containing $0,2,3$ and $6 \mathrm{wt}-\% \mathrm{MgO}$ sintered at $1650^{\circ} \mathrm{C}$ for 8 hours. It can be clearly seen that the addition of $\mathrm{MgO}$ promoted grain growth, this is in agreement with results reported by Viswabaskaran et al [5]. More details on the effect of $\mathrm{MgO}$ addition and sintering parameters on the microstructure, phases present and the densification behaviour were reported elsewhere [29].

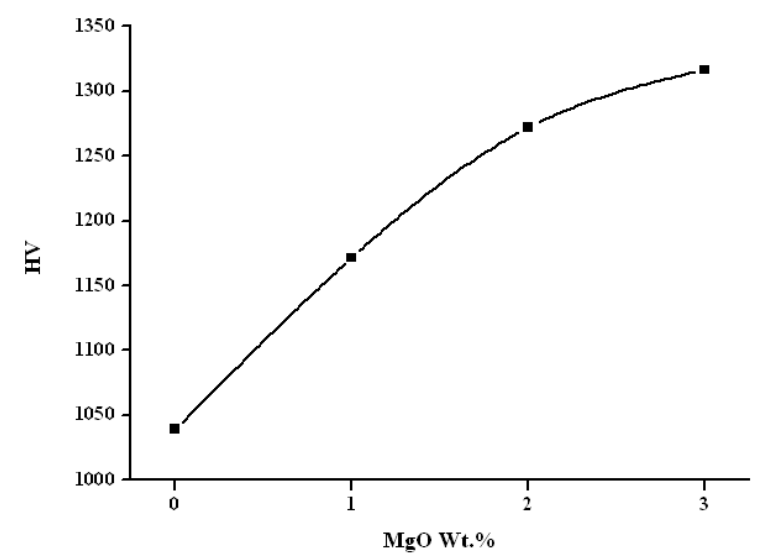

Figure 2. Vicker's hardness of samples sintered 8 hours at $1600^{\circ} \mathrm{C}$.

Figure 2 shows Vicker's hardness of samples containing $0,1,2,3$ wt- $\% \mathrm{MgO}$ sintered 8 hours at $1600^{\circ} \mathrm{C}$. The increase of $\mathrm{MgO}$ content from 0 to $3 \mathrm{wt} \%$ increased the hardness from 1039 to $1316.57 \mathrm{HV}$. The hardness value of
$1039 \mathrm{HV}$ obtained for mullite having a relative density of $93.26 \%$ without addition of $\mathrm{MgO}$ is comparable to that obtained by Hirata et al. [30], who obtained a hardness ranging from 12 to $13 \mathrm{GPa}$ for mullite having relative density between 95.8 and $98 \%$ prepared through sintering pure $\mathrm{Al}_{2} \mathrm{O}_{3}$ and $\mathrm{SiO}_{2}$ for 3 hours at $1550{ }^{\circ} \mathrm{C}$. The increase of the hardness is due to the increase of the relative density of samples with the increase of $\mathrm{MgO}$ content; this trend was also observed by other researchers [5]. It is worth mentioning here that for samples containing 0,1 and 2 wt$\% \mathrm{MgO}$ only mullite was formed while, in addition to mullite, $\mathrm{Al}_{2} \mathrm{O}_{3}$ was present in samples containing 3 wt$\% \mathrm{MgO}$.

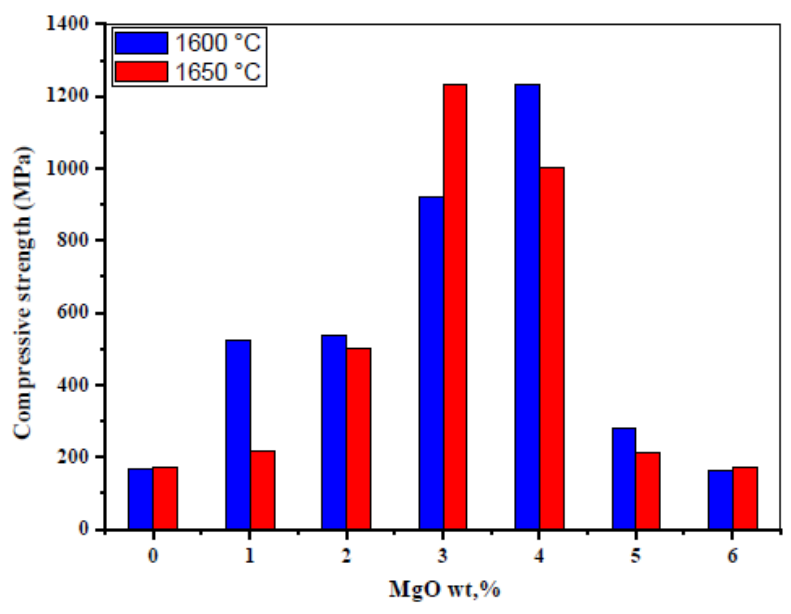

Figure 3. Compressive strength of samples sintered 8 hours at $1600{ }^{\circ} \mathrm{C}$ and $1650^{\circ} \mathrm{C}$.

Figure 3 shows the compressive strength as a function of $\mathrm{MgO}$ content for samples sintered 8 hours at 1600 and $1650^{\circ} \mathrm{C}$. It can be clearly seen that at both temperatures the increase in $\mathrm{MgO}$ content increased the compressive strength up to a maximum then decreased it. A maximum strength of $1234.17 \mathrm{MPa}$ was achieved at a sintering temperature of $1650^{\circ} \mathrm{C}$ for the sample containing $3 \mathrm{wt}-\%$ $\mathrm{MgO}$; and a maximum strength of $1231.31 \mathrm{MPa}$ was achieved at a sintering temperature of $1600^{\circ} \mathrm{C}$ for the sample containing $4 \mathrm{wt}-\% \mathrm{MgO}$. The increase of sintering temperature from 1600 to $1650^{\circ} \mathrm{C}$ increased the compressive strength of sample M0 from 169.59 to 172.64 $\mathrm{MPa}$. In $\mathrm{MgO}$ containing samples the increase of sintering temperature increased the compressive strength in samples M3 and M6 and decreased it in samples M1, M2, M4 and M5. This trend may be due to the presence of deferent phases in the samples. It was shown in previous work [29] that for samples containing 0,1 and $2 \mathrm{wt}-\% \mathrm{MgO}$ only mullite was formed; while, in addition to mullite, $\mathrm{Al}_{2} \mathrm{O}_{3}$ was present in sample containing $3 \mathrm{wt}-\% \mathrm{MgO}$. At higher $\mathrm{MgO}$ content (4, 5 and $6 \mathrm{wt}-\%$ ), three phases, i.e. mullite, $\mathrm{Al}_{2} \mathrm{O}_{3}$ and spinel, were formed. Also, the relative density, open porosity and closed porosity do affect the strength of samples. The relative density, open porosity, and closed porosity of samples sintered 8 hours at 1600 and $1650^{\circ} \mathrm{C}$ are presented in figure 4 . 

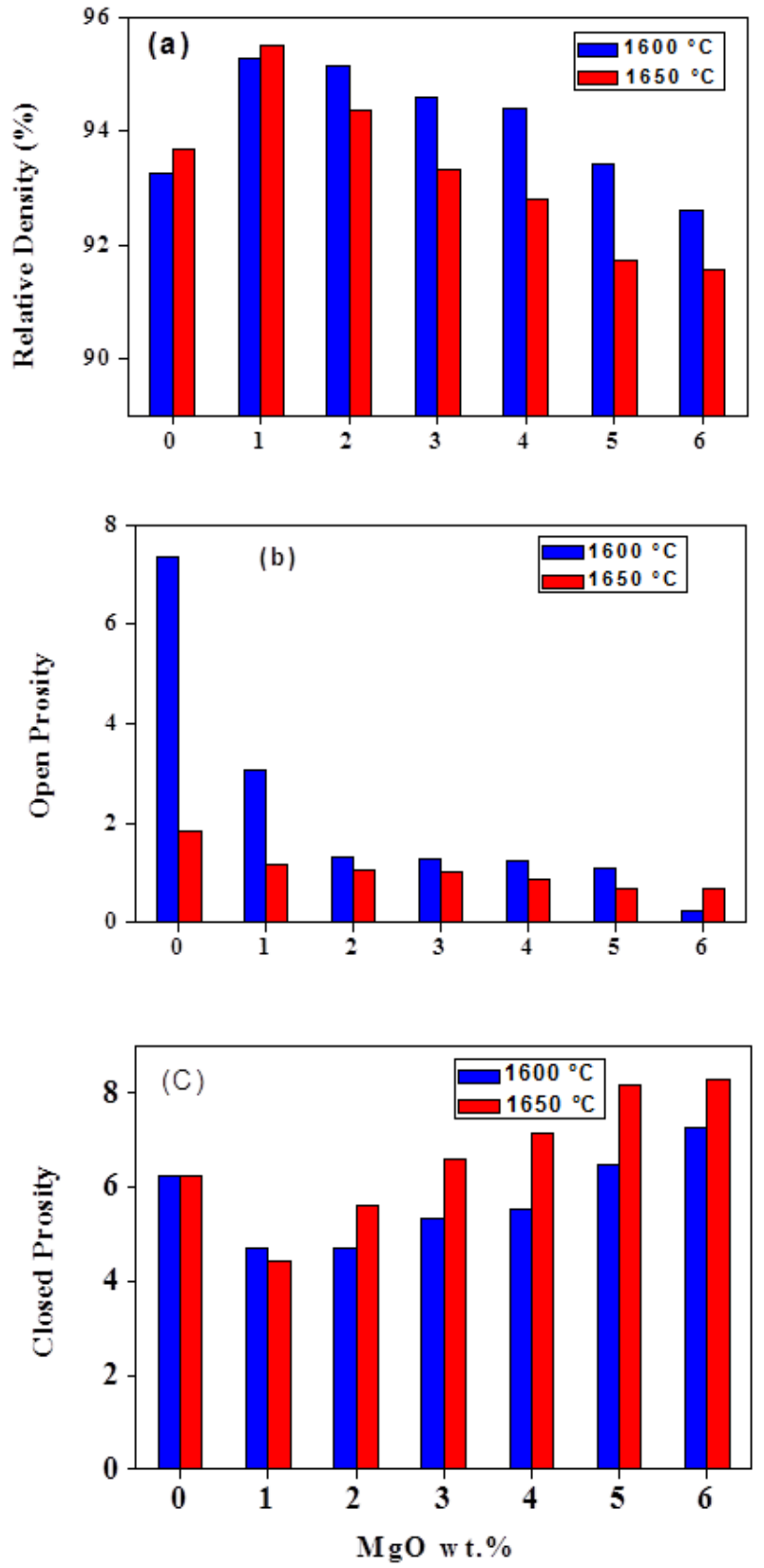

Figure 4. Relative density (a) open porosity (b) and closed porosity (C) of samples sintered 8 hours at $1600^{\circ} \mathrm{C}$ and $1650{ }^{\circ} \mathrm{C}$.

The increase of sintering temperature from 1600 to $1650^{\circ} \mathrm{C}$ slightly increased the relative density of samples M0 and M1 while decreasing the relative density of samples M2, M3, M4, M5 and M6 as can be seen in figure 4(a). The open porosity decreased in all samples with the increase of sintering temperature, as shown in figure 4(b). However, the closed porosity remained unchanged in sample M0, slightly decreased in sample M1, and increased in samples M2, M3, M4, M5 and M6 as can be clearly seen in figure $4(c)$.

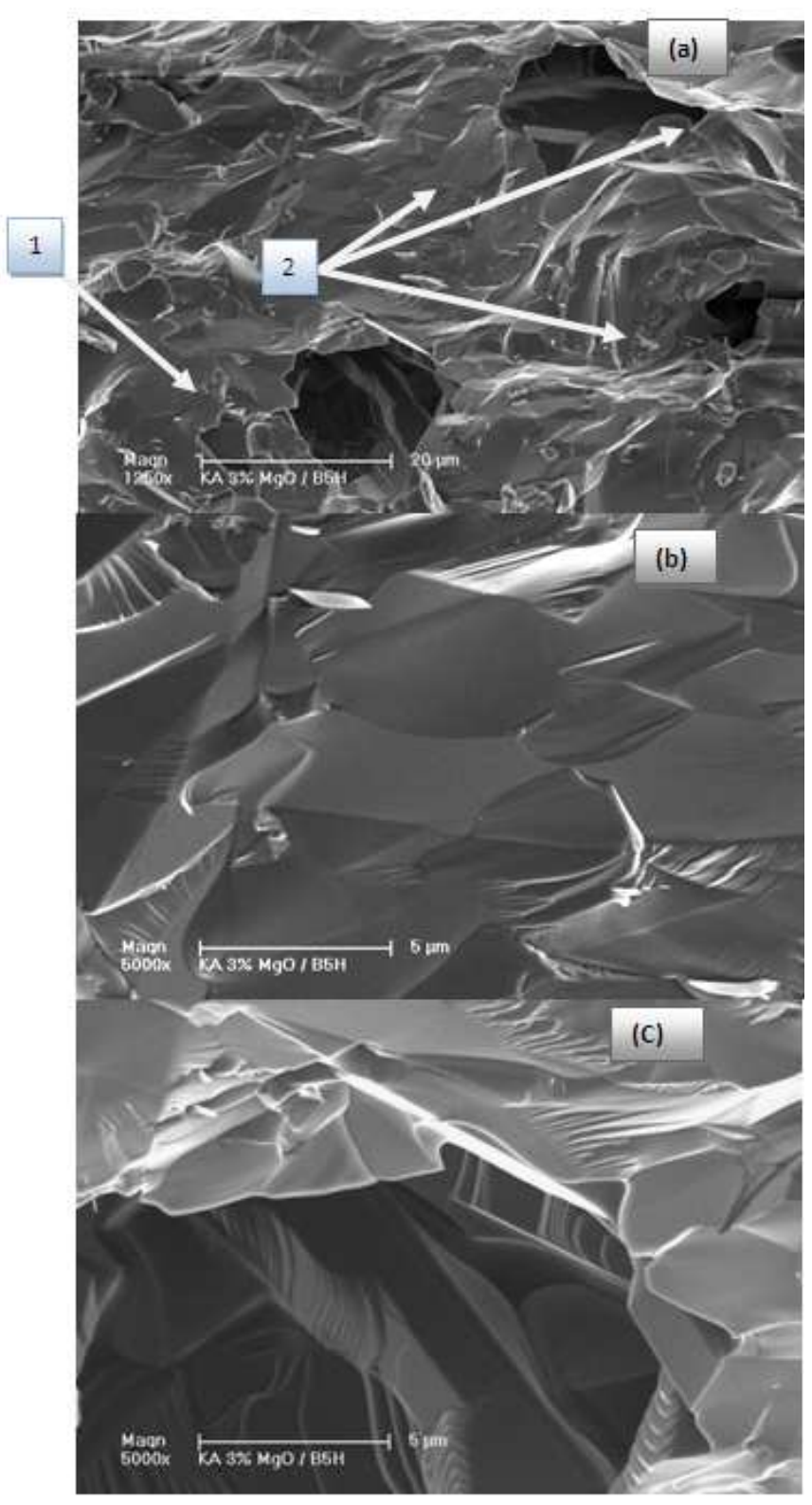

Figure 5. Surfaces of fractured sample containing $3 \mathrm{wt} \% \mathrm{MgO}$ (a) pores and surface markings, (b) higher magnification showing cleavage steps and (c) a river pattern.

Surfaces of fractured sample M3 containing 3 wt- $\% \mathrm{MgO}$ are shown in figure 5. It is clear that the mode of fracture in this sample is transgranular. Pores of deferent sizes and shapes, regions 1 and 2 in figure 5(a), were present on the surface. Also, surface markings and cleavages were observed.

Figure 5(b) shows a magnified view of these surface markings believed to be the cleavage planes. It was reported by Torrecillas and co-workers [31] that the presence of sharp-edged pores at grain boundaries and grain boundary junctions favor the cleavage, with the pores acting as stress concentrators. Figure 5(c) shows typical 'river patterns' which form at the passage of grain boundaries. Because adjacent grains have different orientations, cleavage cracks change directions at grain boundaries to continue propagation [32]. 


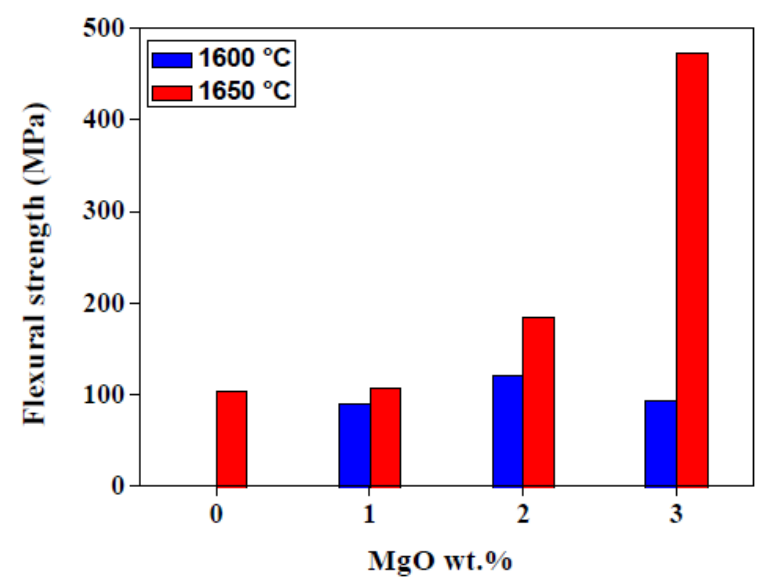

Figure 6. Flexural strength of samples sintered 8 hours at $1600^{\circ} \mathrm{C}$ and $1650^{\circ} \mathrm{C}$.

Figure 6 shows the flexural strength of samples containing $0,1,2,3 \mathrm{wt}-\% \mathrm{MgO}$ sintered 8 hours at 1600 and $1650^{\circ} \mathrm{C}$. For a sintering temperature of $1600{ }^{\circ} \mathrm{C}$, the increase of $\mathrm{MgO}$ content up to $2 \mathrm{wt}-\%$ increased the strength, a further increase up to $3 \mathrm{wt}-\%$ decreased it again. However, for a sintering temperature of $1650^{\circ} \mathrm{C}$, the increase of $\mathrm{MgO}$ content from 0 to $3 \mathrm{wt}-\%$ increased the flexural strength from 103.45 to $472.25 \mathrm{MPa}$. This result is in agreement with that reported by Doni el al. [17] who obtained a maximum flexural strength of $441 \mathrm{MPa}$ for $\mathrm{MgO}$ containing samples.

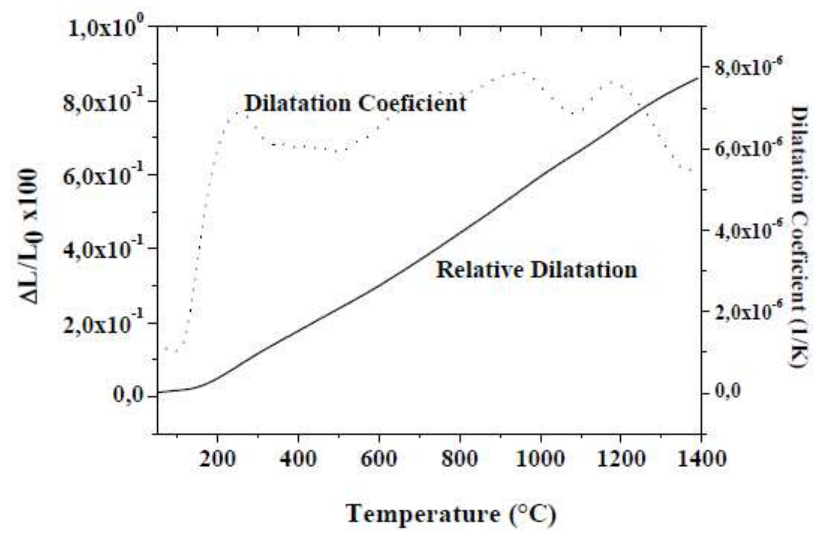

Figure 7. Thermal expansion of sample M0 sintered 8 hours at $1600^{\circ} \mathrm{C}$

Figure 7 shows typical thermal expansion curve of sample M0 sintered 8 hours at $1600{ }^{\circ} \mathrm{C}$. The coefficient of thermal expansion of samples containing $0,1,2$ and 3 wt$\% \mathrm{MgO}$ between room temperature and $1400^{\circ} \mathrm{C}$ is presented in figure 8 . It is clear that for samples containing $\mathrm{MgO}$, the increase of $\mathrm{MgO}$ from 1 to $3 \mathrm{wt}-\%$ increased the coefficient of thermal expansion from $4.25 \times 10^{-6}$ to $4.75 \mathrm{x}$ $10^{-6} \mathrm{~K}^{-1}$. However, the coefficient of thermal expansion of samples containing $\mathrm{MgO}$ remained lower than the coefficient of thermal expansion of samples without $\mathrm{MgO}$ addition i.e. $5.54 \times 10^{-6} \mathrm{~K}^{-1}$. The lower $\mathrm{MgO}$ content, the lower the coefficient of thermal expansion, this is in agreement with results reported by Somiya and co-workers [33].

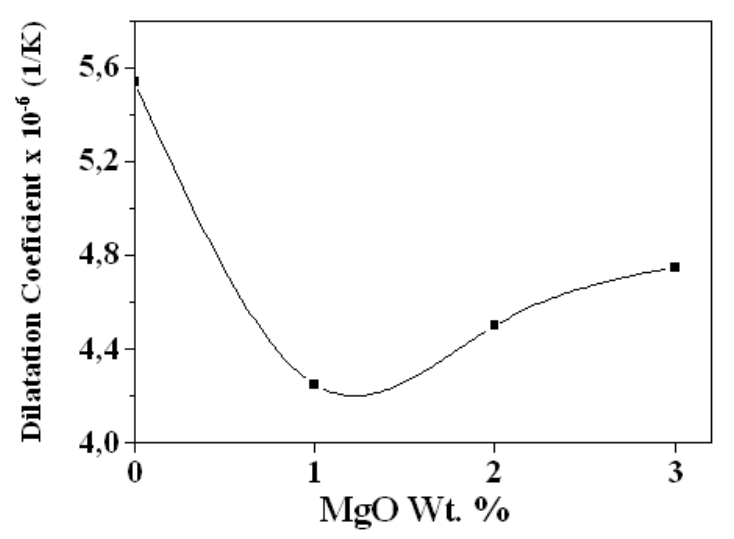

Figure 8. Coefficient of thermal expansion of samples sintered 8 hours at $1600^{\circ} \mathrm{C}$

\section{Conclusion}

In this study the mechanical and thermal properties of mullite prepared through reaction sintering of Algerian kaolin and $\mathrm{Al}_{2} \mathrm{O}_{3}$ were characterized. It was found that the increase of $\mathrm{MgO}$ content from 0 to $3 \mathrm{wt} \%$ increased the hardness of samples sintered 8 hours at $1600^{\circ} \mathrm{C}$ from 1039 to $1316.57 \mathrm{HV}$. Also, the increase of $\mathrm{MgO}$ content in samples sintered 8 hours at 1600 and $1650^{\circ} \mathrm{C}$ increased the compressive strength up to a maximum then decreased it. For a sintering temperature of $1600^{\circ} \mathrm{C}$, the increase of $\mathrm{MgO}$ content up to $2 \mathrm{wt}-\%$ increased the flexural strength, but a further increase of $\mathrm{MgO}$ to $3 \mathrm{wt}-\%$ decreased it again; while for a sintering temperature of $1650^{\circ} \mathrm{C}$, the increase of $\mathrm{MgO}$ content from 0 to $3 \mathrm{wt}-\%$ increased the flexural strength from 103.45 to $472.25 \mathrm{MPa}$. Amongst $\mathrm{MgO}$ containing samples, the increase of $\mathrm{MgO}$ content increased the coefficient of thermal expansion; however, it remained lower than the coefficient of thermal expansion of samples without $\mathrm{MgO}$ addition.

\section{References}

[1] M. Rahmani, K. Jangorban and S. Otroj, Ceramics-Silikaty, 56, 215-221 (2012)

[2] J. Roy, N. Bandyopadhyay, S. Das and , S. Maitra, Ceramics-Silikaty, 54, 128-132 (2010)

[3] H. Belhouchet, M. Hamidouche, N. Bouaouadja, V. Garnier and G. Fantozzi, Ceramics-Silikaty, 53, 205-210 (2009).

[4] V. Viswabaskaran, F.D. Gnanam and M. Balasubramanian, Ceram. Inter., 28, 557-564 (2002)

[5] V. Viswabaskaran, F.D. Gnanam and M. Balasubramanian, Ceram. Inter., 29, 561-571 (2003)

[6] V. Viswabaskaran, F.D. Gnanam and M. Balasubramanian, Appl. Clay Sci., 25, 2935 (2004).

[7] E. Kamseu, S. Braccini, A. Corradi and C. Leonelli, Adv. App. Ceram., 108, 338-346 (2009)

[8] T. Ebadzadeh, M.H. Sarrafi and E. Salahi, Ceram. Inter, 35, 3175-3179 (2009) 
[9] B. Bagchi, S. Das and A. Bhattacharya, R. Basu and P. Nandy, App. Clay Sci., 47, 409-413 (2010)

[10] A. Esharghawi, C. Penot and F. Nardou, J. Eur. Ceram. Soc., 29, 31-38 (2009)

[11] A. Esharghawi, C. Penot and F. Nardou, Ceram. Inter, 36, 231-239 (2010).

[12] F. Sahnoune, M. Chegaar, N. Saheb, P. Goeuriot and F. Valdivieso, App. Clay Sci., 38, 304-310 (2008).

[13] W.E. Lee and W.M. Rainforth, Ceramic Microstructures: Property Control by Processing, Chapman \& Hall, London 1994.

[14] M.G.M.U. Ismail, H. Tsunatori and Z. Nakai, J. Mater. Sci., 25, 2619-2625 (1990)

[15] C. Galassi, E. Roncari, C. Bassarello and R. Lapasin, J. Am. Ceram. Soc., 82, 3453-3458 (1999).

[16] L. Montanaro, C. Perrot, C. Esnouf, G. Thollet, G. Fantozzi and A. Negro, J. Am. Ceram. Soc., 83, 189-196 (2000).

[17] D. Doni Jayaseelan, D. Amutha Rani, D.Benny Anburaj and T. Ohji, Ceram. Inter., 30, 539-543 (2004).

[18] V. Viswabaskaran, F.D.Gnanam and M. Balasubramanian, App. Clay Sci., 25, 29-35 (2004).

[19] W.M.N. Nour and H.M. Awad, J. Aust. Ceram. Soc., 44, $27-$ 37 (2008).

[20] W.M.N. Nour and H.M. Awad, Ce Ca, 38, 111-120 (2008).

[21] D. Amutha Rani, D. Doni Jayaseelan and F.D. Gnanam, $J$. Eur. Ceram. Soc., 21, 2253-2257 (2001).
[22] S.H. Hong, W. Cermignani and G.L. Messing, J. Eur. Ceram. Soc., 16, 133-141 (1996).

[23] S.H. Hong and G.L. Messing, J. Am. Ceram. Soc., 81, 12691277 (1998).

[24] P. Mechnich, M. Schmucker and H.Schneider, J. Am. Ceram. Soc., 82, 2517-2522 (1999).

[25] J. Roy, N. Bandyopadhyay, S. Das and S. Maitra, Ceram. Inter., 36, 1603-1608 (2010).

[26] P.M. Souto, R.R. Menezes and R.H.G.A. Kiminami, J. Mater. Proc. Tech., 209, 548-553 (2009).

[27] F. Sahnoune, M. Chegaar, N. Saheb, P. Goeuriot and F. Valdivieso, Adv. App. Ceram., 107, 9-13 (2008).

[28] F. Sahnoune, N. Saheb B. Khamel and Z. Takkouk, J. Therm. Anal. Calorim., 107, 1067-1072 (2012).

[29] M. Heraiz, A. Merrouche and N. Saheb, Adv. App. Ceram, $105,285-290$ (2006).

[30] Y. Hirata, K. Sakeda, Y. Matsushita, K. Shimada and Y.J. Ishihara, Am. Ceram. Soc., 72, 995-1002 (1989).

[31] R. Torrecillas, J.M. Calderon, J.S. Moya, M.J. Reece, C.K.L. Davies, C. Olagnon and G. Fantozzi, J. Eur. Ceram. Soc., 19, 2519-2527 (1999).

[32] C.D. Beachem: Microscopic fracture processes, Academic Press, Liebowitz 1968.

[33] S. Somiya and Y. Hirata, Am. Ceram. Soc. Bull., 70, 16241632 (1991). 